\title{
Missed Chopart dislocation. The importance of being aware of midtarsal injuries
}

\section{Luxación inveterada de la articulación de Chopart. La importancia de reconocer las lesiones mediotarsianas}

\author{
I. Sancho González ${ }^{1}$, M. Menéndez García ${ }^{2}$
}

http: //dx.doi.org/10.4321/S1137-6627/2016000100019

\section{RESUMEN}

Las luxaciones de la articulación de Chopart (mediotarsiana) son relativamente raras pero potencialmente graves. Su baja prevalencia y la posible ausencia de signos radiológicos obvios no pueden justificar que pasen desapercibidas, puesto que el correcto diagnóstico y tratamiento de estas lesiones es necesario para obtener un buen resultado clínico.

Se presenta el caso de una luxación mediotarsiana en una mujer de 19 años de edad que fue diagnosticada a las ocho semanas de evolución. Se realizó una reducción abierta a través de un doble abordaje (medial y lateral) y una estabilización de las articulaciones con agujas de Kirschner. Al año de la intervención, no se observó pérdida de reducción y la paciente no presentó dolor, pero si limitaciones funcionales para realizar deportes de carrera.

Además de describir el tratamiento de esta lesión tan particular, el presente trabajo pretende aumentar el nivel de sospecha para evitar errores diagnósticos como el ocurrido en nuestro caso.

Palabras clave. Fractura, Luxación. Mediotarsiana. Retraso diagnóstico. Reducción abierta.

\begin{abstract}
Chopart (midtarsal) joint dislocations are relatively rare but potentially serious injuries. Their low prevalence and the possible absence of evident radiological findings cannot justify misdiagnosis because an adequate and correct treatment is required to achieve a proper clinical outcome.

A midtarsal joint dislocation in a 19-year-oldwoman is described, in which diagnosis was performed at 8 weeks of evolution. An open reduction was performed by a double approach (medial and lateral) and a Kirschner wire joint stabilization. At one-year of follow-up, loss of reduction was not observed and the patient was pain-free, although she referred to functional limitation when running.

Besides describing the treatment of this particular injury, this study is aimed at increasing the level of clinical suspicion in order to avoid misdiagnosis such as occurred in our case.
\end{abstract}

Keywords. Fracture. Dislocation. Midtarsal. Delayed diagnosis. Open reduction.
1. Servicio de Cirugía Ortopédica y Traumatología. Hospital Reina Sofía Tudela. Navarra.

2. Servicio de Cirugía Ortopédica y Traumatología. Complejo Hospitalario de Navarra. Pamplona.

Recepción: 5-10-2015

Aceptación provisional: 2-11-2015

Aceptación definitiva: 15-1-2016

\section{Correspondencia:}

Ignacio Sancho González

Servicio de Cirugía Ortopédica y Traumatología Hospital Reina Sofía. Carretera Tudela-Tarazona, km. 3

31500 Tudela. Navarra

Email: ignaciosancho2001@yahoo.es

El autor declara no conflictos de interés ni becas, ni ayudas. 


\section{INTRODUCTION}

The midtarsal joint constitutes the anatomic limit between hindfoot and midfoot. This joint space was described by François Chopart (1743-1795) as a practical level for amputations in cases of distal foot necro$\operatorname{sis}^{1}$. Since then, the midtarsal joint is referred as Chopart joint.

The incidence of midfoot injuries is estimated at 3.6/100.000/year ${ }^{2}$. Their rarity should not be a reason to underestimate them, as they are really complex and potentially serious lesions. Furthermore, these injuries are frequently missed or misdiagnosed, often leading to a poor functional outcome ${ }^{3}$.

In the present study a midtarsal joint dislocation of eight weeks of evolution is reported which it was reduced through a double medial and lateral approach. Several series of cases of midtarsal fracturedislocations are reported in the literature; however the data available on inveterate injuries is still scarce and its management it is not well defined.
The present study has several objectives. The first aim is to present the case and its treatment. Secondly, several key points for a proper diagnosis are given with the aim of reducing cases of misdiagnosis. Finally, the related literature is reviewed.

\section{CASE REPORT}

Nineteen-year-old woman who came to our ambulatory trauma service with the diagnosis of a sprained right ankle for evolutionary control.

The patient reported, as the only history of interest, trauma eight weeks ago, in which she struck a heavy cabinet directly over the foot in plantar flexion. She immediately felt local pain and swelling.

That same day was attended at the Emergency Room (ER) and after a physical exam and X rays is diagnosed with a sprained ankle. She was treated with a bandage and acetaminophen 1 gram every eight hours and was allowed ongoing support weight bearing using two crutches.

Given the poor evolution, with persistent pain and walking impairment, the patient returned to the ER at 6 weeks of the trauma suffered.

On her second visit to ER also a not clear diagnosis was achieved. She was immobilized

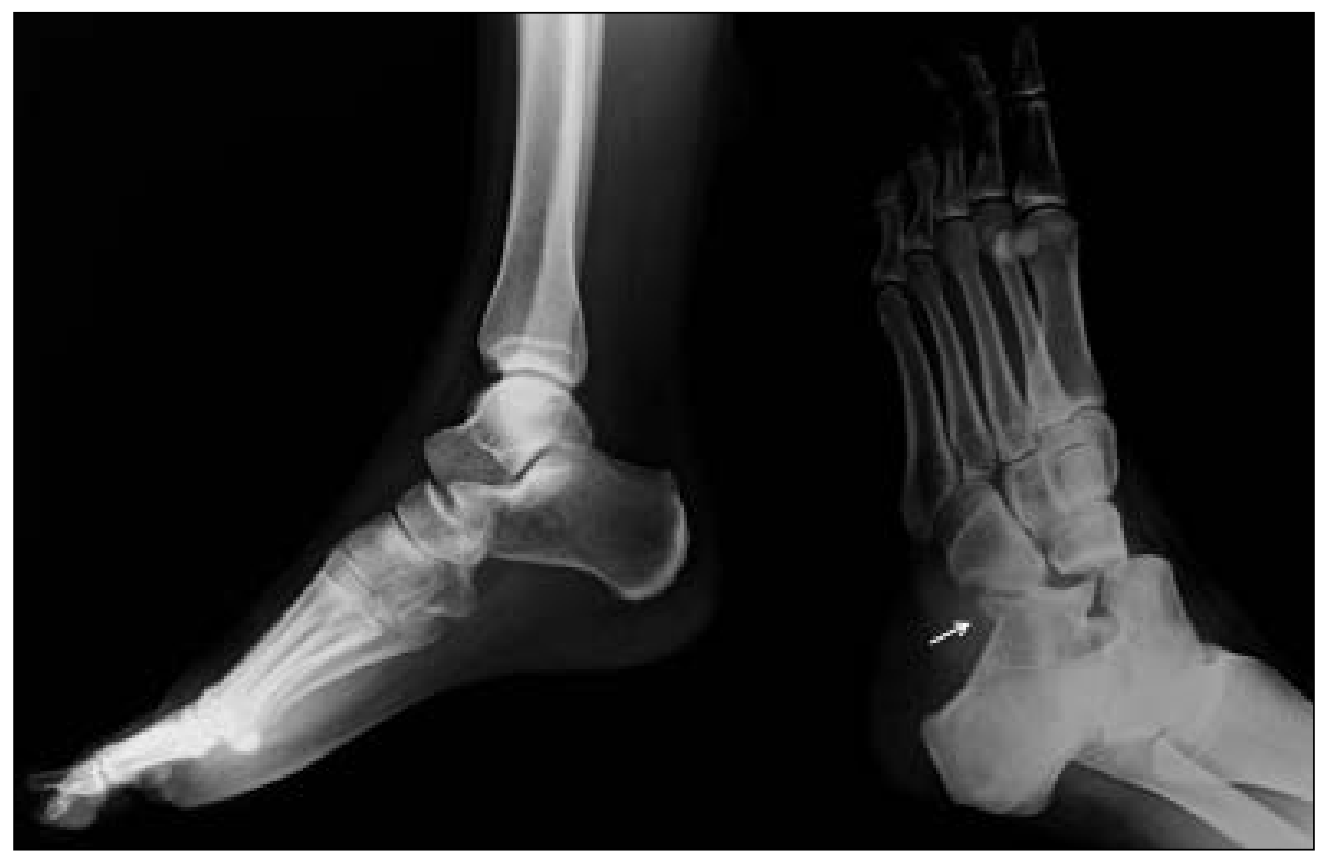

Figura 1. Lateral and oblique radiographs. Plantar Chopart dislocation and associated Nutcracker cuboideal fracture (white arrow) are observed. 
with a cast and cited at the ambulatory trauma service.

There was not swelling on the inspection, there were neither bruising nor skin changes. Tibiotalar joint mobility was preserved, and no painful. Palpation was painful over the navicular bone and it drew attention to the flattening of the inner arch of the foot compared to the contralateral side.

Firstly the reevaluation of emergency radiographs was performed, finding a midtarsal joint plantar dislocation and an associated calcaneal fracture that had gone unnoticed (Fig. 1).

Computed tomography (CT) was requested. Definitive diagnosis after evaluation of CT images was midtarsal dislocation of the right foot with associated fracture of the anterolateral calcaneus process (Nutcracker fracture) and osteochondral fracture of the talar head of approximately 8 weeks of evolution.

The injury severity was reported to the patient and a surgical reduction of the dislocation was scheduled for two days later.

In the supine position, under general anesthesia, access to the midtarsal joint was performed through a two-way medial and lateral approach. After careful debridement of fibrous interposed tissue in the Chopart space, congruence of talonavicular and calcaneocuboidal joints was achieved. Under fluoroscopic control it was performed percutaneous osteosynthesis with Kirschner wires through both joints. Then it proceeded to carefully repair capsulo-ligamentous structures. The intervention ended with the limb immobilization with a short leg cast.

At 48 hours after surgery the patient was discharged, after skin condition and postoperative radiographs were controlled.

Six weeks post-surgery, hardware and immobilization were removed. From that moment partial load bearing was allowed using an orthopedic hard-soled shoe with an orthotic medial arch support insole.

Past 12 months after surgery loss of reduction was not observed. The patient had no foot pain either at rest or walking, but referring some functional limitation when running. The American Orthopaedic Foot and Ankle Society (AOFAS) Midfoot Score $^{4}$ was 74 at this point follow-up.

\section{DISCUSSION}

The midtarsal is a low mobile but essential joint for proper mechanics and architecture of the foot. It is composed of the condyloid talonavicular joint and the saddle-shaped calcaneocuboidal joint. Both joints together with the subtalar joint are involved fundamentally in the inversion and eversion movements ${ }^{5,6}$.

Trauma to this region may cause fractures and/or dislocations. Loss of joint congruence and stability in this region jeopardizes the whole function of the foot and a normal gait $^{7,8}$. Complex midfoot injuries could lead to severe functional impairment of mobility and quality of daily living.

The main causes of midtarsal dislocation are motor vehicle accidents and falls from a height ${ }^{3,9}$. In most of the cases are due to axial loads or torsional forces acting on the foot in plantar flexion. Often, these lesions occur in cases presenting a varuscavus foot morphotype ${ }^{10}$.

The heterogeneity and complexity of midtarsal dislocations and fracture-dislocations hampers the existence of an international consensus classification.

Main and Jowett ${ }^{11}$ attempted to classify these injuries into five types according to the direction of the deforming force and the resulting displacement: medial, longitudinal, lateral, plantar and crush injuries. The frequency is by far the highest for the medial and plantar dislocations. They can be pure dislocations (i.e. exclusively capsulo-ligament injuries) or they can be part of complex lesions associating fractures of the talus head, calcaneus, navicular or cuboid $^{3,9,11,12}$.

The cuboid and distal calcaneus fractures, typically associated to midtarsal dislocations, produced by forced abduction or adduction (lateral or medial stress) are known as Nutcracker fractures. These lesions tend to be underestimated but they are potentially serious ${ }^{13}$.

Finally deserves special attention the combined Chopart and Lisfranc dislocation, rare but especially serious.

Delay in diagnosis is common and may adversely affect the long-term prognosis ${ }^{3}$. Chopart fracture-dislocations are missed or misdiagnosed in up to $41 \%$ of cases $^{3,7,11}$. The reasons for misdiagnosis could be their low prevalence and the absence of obvious radiological signs in up to a third of cases $^{5,14}$. 
Obtaining radiographs of the foot in three projections (anteroposterior, lateral and oblique) is essential. The talus-medial cuneiform-first metatarsal axis should be lined up on both a lateral and anteroposterior radiograph. Another important marker of midfoot injury is the S-shaped Cyma line on lateral radiographs, sign of congruence of the talonavicular and calcaneocuboidal joints. Finally, the avulsion fracture of the dorsal talonavicular ligament caused by additional plantar flexion forced serves as radiological marker for serious ligamentous injury with midtarsal instability ${ }^{15}$.

CT offers additional information when associated lesions or to plan future treatments and is not hesitating to apply if diagnosis is unclear.

All dislocations should be reduced emergently if possible, and all these eventually associated fractures must be reduced and correctly fixed. The ultimate goal is to restore alignment and length in both columns of the foot, medial and lateral, getting proper congruence in the joints and ligamentous stability.

Close reduction is a valid procedure in subluxations, acute dislocations when anatomy could be perfectly restored or in cases where surgery is contraindicated ${ }^{5,9}$.

Chopart dislocations with associated injuries, open reduction and fracture fixation represents the best option and allow reparation of damaged capsulo-ligamentous structures.

Joint stabilization with Kirschner wires (1,6-2mm) once the congruence is restored, may provide additional stability and could be performed after either open or close reduction.

Inveterate dislocations are also an indication of open reduction. In the delayed setting careful debridement of the Chopart space is essential. The surgical correction of the length and shape of the longitudinal arch is important and technically challenging especially in combined Chopart-Lisfranc injuries ${ }^{9}$.

According to $\mathrm{Klaue}^{10}$ we thought the double approach is the best way to treat these injuries by ensuring accessibility to both joints. Both approaches are safe and allow proper display of the key elements.

- Anteromedial approach: exposes correctly the talonavicular joint and allows if necessary to synthesize the scaphoid.

- Anterolateral approach (Ollier): requires partial proximal detachment of the extensor digitorum brevis muscle. It exposes perfectly the calcaneocuboidal joint. It requires careful dissection and protection of the peroneus superficialis and suralis nerves (Fig. 2).

Routine postoperative measures include rigid immobilization and no-weight bearing for a period of six to eight weeks. Kirschner wires in appropriate cases are left equally implanted during this period.

Subsequently, the patient should begin gradual partial and controlled weigh bearing using a custom molded foot orthotics and crutches. We recommend using orthotic insoles providing longitudinal arch support in order to prevent loss of reduction after starting to walk.

Exercises that strengthen and stretch the gastrocnemius should be emphasized to the patient. Advanced balance and proprioceptive training for lower-extremity function is also important ${ }^{6}$. Three months postoperatively may be the time to begin normal shoe wearing ${ }^{5}$.

An alternative to this method of treatment may be external fixation, especially given the existence of serious soft tissue injury or when the lateral and medial columns are seriously fractured and shortened.

Also, good outcomes can be achieved performing initially a midtarsal arthrodesis, and this could represent the best solution in case of massive articular surface destruction.

Greater series reported ${ }^{3,7,9}$ agree on a set of conclusions in terms of outcomes but they all refer to acute lesions. Open reduction and internal fixation is the most precisely method restoring the anatomy and thus gets the best functional outcomes. There are not great differences in prognostic terms comparing pure dislocations 


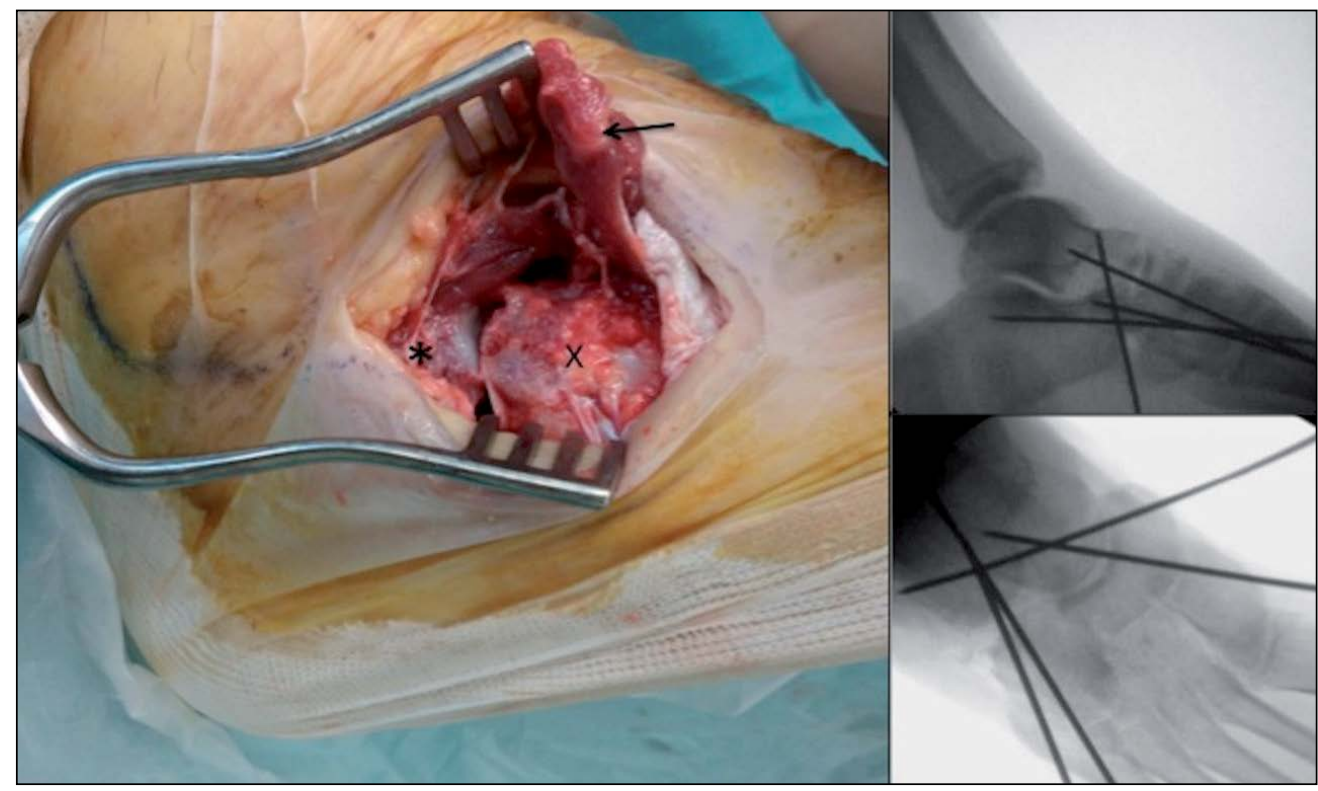

Figura 2. Left: Anterolateral approach to the joint between the calcaneus $\left(^{*}\right)$ and cuboid $(\mathrm{X})$. Partial detachment of the extensor digitorum brevis (arrow) is needed. Right: Intraoperatory X-Ray. Restoration of the talus-medial cuneiform-first metatarsal axis and the S-shaped Cyma line, are observed.

and fracture-dislocations. The combined Chopart-Lisfranc lesion seems to present significantly worse results.

In cases of poor outcome and at the persistence of pain will be indicated salvage procedures including osteotomies and arthrodesis.

In conclusion, handling Chopart injuries is challenging and even more in the delay setting. We hope the reported case may be helpful to orthopedic surgeons facing similar cases and increasing awareness about this rare but serious entity.

\section{BIBLIOGRAFÍA}

1. Fourcroy AF. La médecine éclairée par les sciences physiques 1972; Tomo 4 París: 8588.

2. Court-Brown, CM, Zinna S, Ekrol I. Classification and epidemiology of mid-foot fractures. Foot 2006; 16: 138-141.

3. VAn Dorp KB, De VRies MR, VAn Der Elst M, SCHEPERS T. Chopart joint injury: A study of outcome and morbidity. J Foot Ankle Surg 2010; 49: 541-545.
4. Kitaoka HB, Alexander IJ, Adelaar RS, Nunley JA, Myerson MS, SANDERs M et al. Clinical rating systems for the ankle-hindfoot, midfoot, hallux, and lesser toes. Foot ankle Int 1994; 15: 349-353.

5. Benirschie SK, Meinberg EG, Anderson SA, Jones CB, ColE P. Fractures and dislocations of the midfoot: Lisfranc and Chopart injuries. Instr Course Lect 2013; 62: 79-91

6. Swords MP, Schramski M, Switzer K, Nemec S. Chopart fractures and dislocations. Foot Ankle Clin 2008; 13: 679-693.

7. Kösters C, Bockholt S, Müller C, Winter C, RoSEnBaum D, RaschKe MJ et al. Comparing the outcomes between Chopart, lisfranc and multiple metatarsal shaft fractures. Arch Orthop Trauma Surg 2014; 134: 1397-1404.

8. Mittlmeier T, Krowiorsch R, Brosinger S, Hudde M. Gait function after fracture-dislocation of the midtarsal and/or tarsometatarsal joints. Clin Biomech 1997; 12: 16-17.

9. Richter M, Thermann H, Huefner T, Schmidt U, GoesLing T, KRETTEK C et al. Chopart joint fracture-dislocation : initial open reduction provides better outcome than closed reduction. Foot Ankle Int 2004; 25: 340-348.

10. KlaUE K. Chopart fractures. Injury 2004; 35 : 64-70. 
11. Main BJ, Jowett RL. Injuries of the midtarsal joint. J Bone Joint Surg Br 1975; 57: 89-97.

12. IP KY, LuI TH. Isolated dorsal midtarsal (Chopart) dislocation: a case report. J Orthop Surg (Hong Kong) 2006; 14: 357-359.

13. Hermel Mb, Gershon-Cohen J. The nutcracker fracture of the cuboid by indirect violence. Radiology 1953; 60: 850-854.
14. HaApamaki VV, Kiuru Mj, Koskinen SK. Ankle and foot injuries: analysis of MDCT findings. Am J Roentgenol 2004; 183: 615-622.

15. Schmitt JW, Werner CML, Ossendorf C, WANner GA, Simmen H-P. Avulsion fracture of the dorsal talonavicular ligament: A subtle radiographic sign of possible Chopart joint dislocation. Foot Ankle Int 2011; 32: 722-726. 